\title{
A Novel Fluid Flow Demonstration/Unit Operations Experiment
}

\author{
Ronald J. Willey, Guido Lopez, Deniz Turan, Ralph A. Buonopane, and \\ Alfred J. Bina \\ Department of Chemical Engineering, Northeastern University, Boston, MA \\ 02115
}

\begin{abstract}
Demonstration of laminar and turbulent flow using water in one experimental unit has always been a challenge. One can achieve one of the two defined flow regimes by varying tube diameter; however, the versatility to move across a decade or more in Reynolds number with a single tube diameter is generally difficult. A unit operations fluid flow experiment composed of a two $3 / 4$-inch ID glass tubes, 36 inches long, has been developed that allows demonstration of flow in all flow regimes with ease. One of the tubes is empty and contains no flow elements (typical flow inside a pipe); the other tube contains a multi-element, 33-inch long, static mixer. Using a secondary dye injection system, students conduct experiments in which the various flow regimes (laminar, transition, or turbulent) may be observed in the empty tube. The effects of the static mixer blending the dye into the water stream can be observed in the other tube. Students record the flow effects in their experiments using still and motion digital photography. Pressure transducers, located at the entrances and exits of the tubes, allow quantitative measurement of pressure drop across each tube to be observed. Students can then compare their results with pressure loss predictions using information found in the literature such as a Fanning Friction Chart. The experiment has been technically successful and is very popular with our students. This paper presents the evolution of this experiment and on the results that students are able to observe and evaluate.
\end{abstract}

\section{Nomenclature}

D Inside diameter of pipe or tube, $\mathrm{m}$

F Frictional pressure losses in flow systems, $\mathrm{m}^{2} / \mathrm{s}^{2}$

f Fanning friction factor, dimensionless

$f_{M} \quad$ Moody friction factor, dimensionless

$\mathrm{L} \quad$ Length of tubing, $\mathrm{m}$

$\mathrm{L}_{\mathrm{eq}} \quad$ Equivalent length of tubing for similar pressure drop, $\mathrm{m}$

P System pressure, $\mathrm{N} / \mathrm{m}^{2}$

Re Reynolds number (defined in Equation 1), dimensionless

$\mathrm{V} \quad$ velocity, $\mathrm{m} / \mathrm{s}$

$\stackrel{\circ}{\mathrm{V}} \quad$ Volumetric flow rate, $\mathrm{m}^{3} / \mathrm{s}$

Subscripts

1 Entrance condition

2 Exit condition

ref Reference condition

"Proceedings of the 2003 American Society for Engineering Education Annual Conference \& Exposition Copyright (C) 2003, American Society for Engineering Education” 


\section{Greek Letters}

$\Delta \quad$ Difference between points 2 and 1 in a flow system

$\mu \quad$ viscosity, $\mathrm{kg} / \mathrm{m} \mathrm{s}$

$\rho$ density, $\mathrm{kg} / \mathrm{m}^{3}$

\section{Introduction}

The visualization of flow streams began with the work of Reynolds. He began the experiments in 1880 and published the results in $1883^{1}$. He sought to explain the first power variation of pressure drop with velocity for capillary diameter tubes according to Poiseuille ${ }^{2}$ and the second power variation of pressure drop with velocity for large diameter tubes according to Darcy ${ }^{3}$. His breakthrough came with the design of an experiment that consisted of a small stream of colored water injected into a larger diameter stream flowing inside glass tubes and tanks. The glass allowed for visualization of the colored flow stream. Figure 1 shows one of the several apparatuses that Reynolds and his colleague designed to study flow regimes. He witnessed two major regimes for flow - laminar and turbulent (see original drawings in Figure 2). Gradually, he was able to predict the factors governing the flow regimes. He compared observations to several variable combinations such as the product of the velocity times the diameter and the ratio of the density to the viscosity - finding that certain things held constant. One of his key techniques included the careful determination and variation of water temperature - something ignored by previous researchers. His experiments allowed for a variation in the ratio of density over viscosity by varying temperature $\left(4\right.$ to $\left.22^{\circ} \mathrm{C}\right)$. Eventually, he was able to predict flow regimes based on one dimensionless group - now known in science and engineering as the Reynolds number.

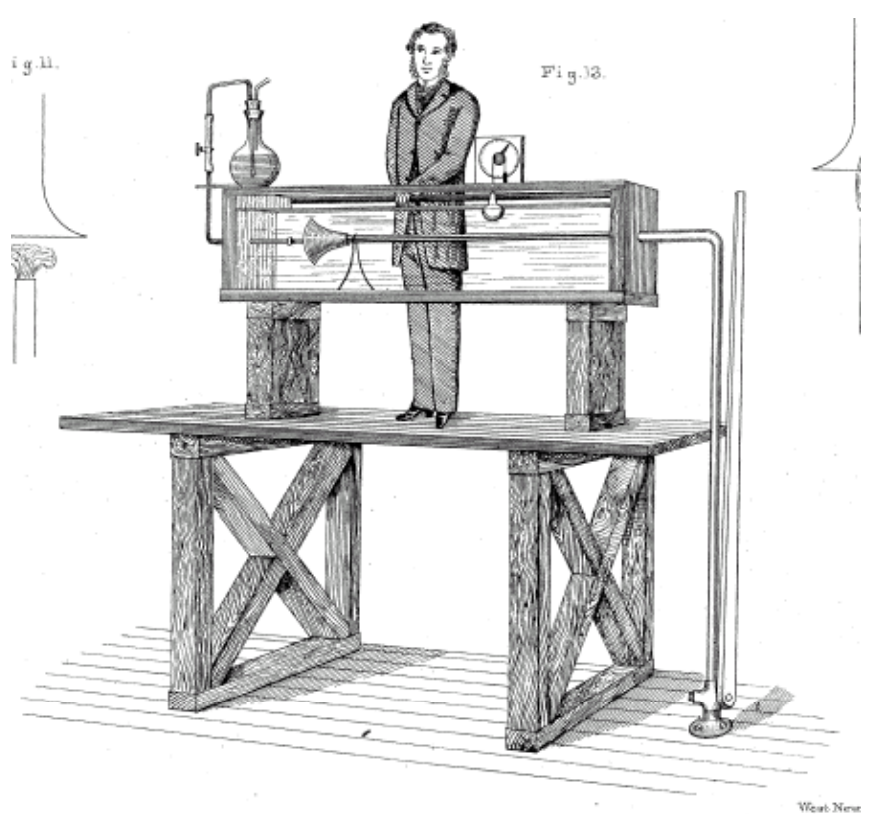

Figure 1. Drawing of one of Reynolds' original apparatus ${ }^{1}$ 
(1.) When the velocities were sufficiently low, the streak of colour extended in a beautiful straight line through the tube, fig. 3 .

Fig. 3.

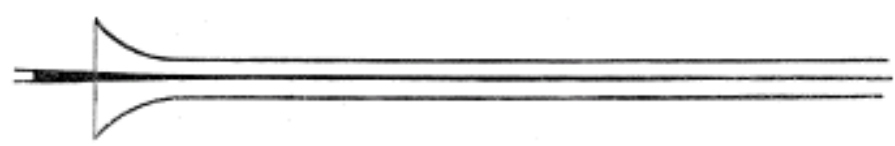

(2.) If the water in the tank had not quite settled to rest, at sufficiently low velocities, the streak would shift about the tube, but there was no appearance of sinuosity.

(3.) As the velocity was increased by small stages, at some point in the tube, always at a considerable distance from the trumpet or intake, the colour band would all at once mix up with the surrounding water, and fill the rest of the tube with a mass of coloured water, as in fig. 4 .

Fig. 4.

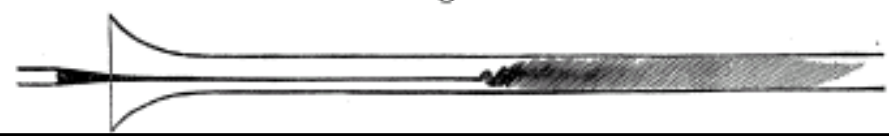

Figure 2. Figures from Reynolds' original paper that showed the major flow regimes ${ }^{1}$

$$
\operatorname{Re}=\frac{\mathrm{v} D \rho}{\mu}
$$

The history and details about Osborne Reynolds are fascinating and the reader can gain some insight into his career at the University of Manchester website 4 . His portrait is also available on the $\mathrm{web}^{5}$.

The duplication of Reynolds' experimental setup has been done in many ways. For example, major work appeared in the 1930's for streamlines photographed around submerged objects (see Batchelor for various plates of photographs) ${ }^{6}$. More recently, experiments and photographs can be found on the Internet. Flometrics offers a commercial unit for experimental demonstration ${ }^{7}$. Rowan University ${ }^{8,9}$ and Rossi ${ }^{10}$ offer further details about fluid flow experiments and the numerical analysis related to such. An excellent CD-ROM available from Cambridge University Press contains many types of visual flow patterns ${ }^{11}$. Examples include "Low Reynolds Number Flow" copyright by Educational Development Center, Inc. Newton, MA, and Rotating Tanks, copyright by B.R.Munson and Stanford University. Other recent papers related to fluid mechanic experiments are listed in the references below ${ }^{12,13}$. Given below is our information on a liquid flow demonstration module integrated into our undergraduate laboratory that builds upon these excellent contributions.

\section{Equations used to analyze data}

The equations used to analyze the data are presented below. Equation 2 is the modified Bernoulli Equation for flow through constant diameter horizontal pipes. The work term, the velocity head term, and the gravity head changes are zero because no pump exists between the two points of pressure measurement, the entrance diameter equals the exit diameter, and no

"Proceedings of the 2003 American Society for Engineering Education Annual Conference \& Exposition Copyright (C) 2003, American Society for Engineering Education" 
change in elevation occurs. The term "F" represents the frictional pressure losses due to flow between the two points of measurement.

$$
F=\frac{P_{1}-P_{2}}{\rho}=\frac{-\Delta P}{\rho}
$$

Equation 3, often called the Darcy-Weisbach equation, is the generalized relationship between "F" and the velocity head, pipe length, and pipe diameter. The proportionality constant, $\mathrm{f}$, is the Fanning friction factor, commonly used by chemical engineers. The Fanning friction factor is related to $f_{M}$, the Moody (or Darcy) friction factor commonly used by civil and mechanical engineers $^{14}$, by a factor of $4\left(f_{M}=4 f\right)$.

$$
F=4 f \frac{L}{D} \frac{\mathrm{v}^{2}}{2}
$$

Over the years many correlations for Fanning friction factors have been developed. For the sake of simplicity we will concentrate on only two of the simpler correlations. Based on the work of Poiseuille $^{2}$ for flow in laminar regions, the friction factor is given as 16 divided by the Reynolds number (Eqn 4). This is true for laminar flow in all type of pipes regardless of roughness. The resultant pressure drop prediction as a function of flow rate is given in Eqn. 5 (the HagenPoiseuille Equation). We see that pressure drop is first order in flow rate (or velocity) as reported in the work of Poiseuille ${ }^{2}$.

$$
\begin{gathered}
f=16 / \operatorname{Re} \\
\Delta P=\frac{32 \mu \mathrm{v} L}{D^{2}}=\frac{128 \mu \dot{V} L}{\pi D^{4}}
\end{gathered}
$$

Transition from laminar to turbulent flow begins around $\mathrm{Re} \sim 1,000$ for rough pipes, and can occur at Re as high as 2,400 for very smooth pipes. After the transition to turbulent flow, the Fanning Friction factor for smooth pipes can be estimated by the Blasius Equation ${ }^{14}$ (Eqn 6). The resultant predicted pressure drop as a function of flow rate is given in Eqn 7. We see that the pressure drop is function of flow rate to the 1.75 power in this relationship. One of the results reported in Reynolds original paper was that for very smooth surfaces, the pressure drop in the turbulent regime was proportional to the 1.7 to 1.9 power of the flow rate and depended upon the pipe material investigated. Previously, Darcy ${ }^{3}$ treated the pressure drop as a $2^{\text {nd }}$ order relationship with flow rate.

$$
\begin{gathered}
f=0.079 \mathrm{Re}^{-0.25} \\
\Delta P=\frac{0.158 \mu^{0.25} \mathrm{v}^{1.75} L \rho^{0.75}}{D^{1.25}}=\frac{0.241 \mu^{0.25} \dot{V}^{1.75} L \rho^{0.75}}{D^{4.75}}
\end{gathered}
$$

For systems with obstructions, enlargements, and contractions, the pressure drop is often related to the velocity head (the square of the velocity divided by 2) based on a reference diameter. Once a reference diameter is selected, the equivalent length of pipe that gives the same pressure drop can be determined experimentally based on pressure drop measured between two horizontal

"Proceedings of the 2003 American Society for Engineering Education Annual Conference \& Exposition Copyright (C) 2003, American Society for Engineering Education" 
points. Eqn 8 (laminar flow) and Eqn 9 (turbulent flow) are equations that can be used to estimate the equivalent length of smooth pipes using Eqns 4 and 6 for the friction factor.

$$
\begin{aligned}
& \text { Equivalent length for laminar flow } \quad L_{e q}=\frac{\Delta P \pi D_{r e f}^{4}}{128 \mu \dot{V}} \\
& \text { Equivalent length for turbulent flow } L_{e q}=\frac{4.15 \Delta P D_{r e f}^{4.75}}{\mu^{0.25} \dot{V}^{1.75} \rho^{0.75}}
\end{aligned}
$$

\section{Methods}

\section{Description of the experimental module}

Originally, the experimental module began as a unit for continuous $\mathrm{pH}$ control. Over the course of construction, we decided to incorporate a liquid flow experiment using the same equipment. Major modifications made as the experiment evolved over the past 3 years included the addition of a head tank and separate dye tank for laminar flow, and the addition of another DP-cell (DP2) to assist in taking pressure drop measurements in the turbulent flow range for the tube containing the static mixer (SG2 described below). Details about the specifications for the components are listed at the end of the paper in Table 2. Figure 3 is a photograph of our module while Figure 4 is a simplified schematic showing the major components.

For the laminar flow regime experiments, flow is directed from two head tanks (labeled T1 and T2) located above the sight glasses (labeled SG1 and SG2). The top head tank (T1) contains dyed water created by adding a tracer tablet to 1 gallon of water. This stream flows through the injection tube (Figure 5) and is controlled by a needle valve. The supply tank, T2, located just below $\mathrm{T} 1$ supplies water for flow through the sight glasses. It has been designed to maintain a constant head by using a continuous feed of water with an overflow. Flow control is achieved by manipulating valve V2. A dial scale was added to allow students the ability to note their valve position and obtain repeated measurements.

Turbulent flow is achieved by using a reservoir (T3 or T4) and a $0.5 \mathrm{hp}$ pump (P1). Injection of dye for this portion of the experiment is achieved using a pulsating pump (P3) fed from another reservoir containing the dye (T6). Valving and piping are in place to alternate the flow sources and receivers depending on the results desired. Flow control is achieved by manipulating valve V6. This $1 / 2$-turn valve has graduations from 0 to $180^{\circ}$ in $15^{\circ}$ markings that allow students to set the valve at repeated positions.

Two variations of sight glasses exist on the experiment. One sight glass, SG1, is empty and represents flow through a smooth tube. Its length is 36 inches and its internal diameter is 0.75 inches. The other sight glass, SG2, is identical to SG1 except that it contains 8 elements of a Stata-tube ${ }^{\mathrm{TM}}$ static mixer. The static mixer achieves mixing by repeatedly dividing the streamlines via elements. Figure 6 is a photograph of the static mixer used in this work.

Differential pressure measurements are made by one of three instruments depending on the flow regime and the sight glass being tested. For laminar flow in SG1, the only reliable measurement

"Proceedings of the 2003 American Society for Engineering Education Annual Conference \& Exposition Copyright (C) 2003, American Society for Engineering Education" 
device found to date is an red oil incline manometer. The (dp) is very low, below 1" water, and the manometer is sensitive to $0.01 " \mathrm{H}_{2} \mathrm{O}$. The pressure transducers are not sensitive enough at (dp)s below 0.1 " $\mathrm{H}_{2} \mathrm{O}$. A 0.1 to $30 " \mathrm{H}_{2} \mathrm{O}$ DP-cell (DP1) is used for (dp) measurement on SG1 in turbulent regime and SG2 in the laminar regime. Finally, a 10 to 750 " $\mathrm{H}_{2} \mathrm{O}$ DP-cell (DP2) is used for SG2 in the turbulent regime. The pressure taps should be mounted on the glass tubes at each end; however, equipment restrictions dictated locating them as close as possible to the glass ends on PVC pipes.

Flow rates are measured by one of two instruments or by direct measurement (bucket and stop watch). For very low flow rates (below 0.1 gallons per minute), the bucket and stop watch method was used because electronic balances sensitive to 0.01 grams are available. Good accuracy with this method of collecting water over a period of 1 minute was achieved. A low flow turbine flow meter (LFT), 0.1 to 1 gallon per minute, is used for the intermediate flow rates and a 0.25 to 9 gpm turbine meter (HFT) is used for the higher flow rates evaluated on this module.

One modern feature that makes data acquisition more convenient compared to Reynolds' day is the use of a microcomputer for data acquisition. Northeastern University Chemical Engineering Department has a long term relationship with Laboratory Technologies, Inc. of Andover, Massachusetts. Labtech Control Pro software enables the acquisition of voltages sent by transducers and flow measuring devices. Keithley Metrabyte interfaces were used for the data acquisition hardware (DAS-8PGA and Exp-16 terminal boards). It is very easy to acquire 10 measurements per second and smooth these over 1 minute and 3 minute periods to obtain the excellent data shown below. For another reference to faculty integrating data acquisition into the laboratory see the work of Henry ${ }^{15}$.

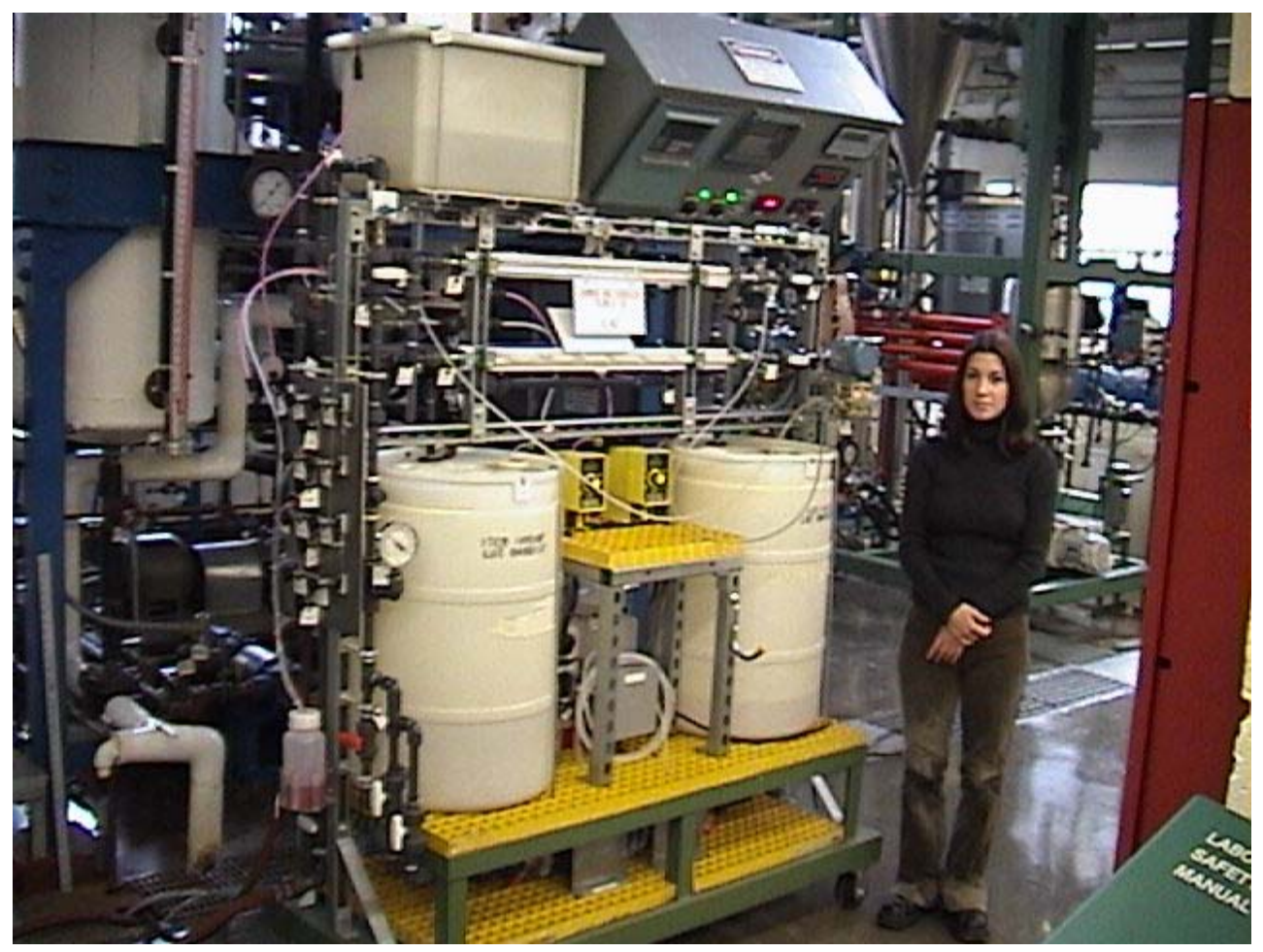

Figure 3. Laminar/Turbulent Flow Demonstration Module

"Proceedings of the 2003 American Society for Engineering Education Annual Conference \& Exposition Copyright (C) 2003, American Society for Engineering Education" 


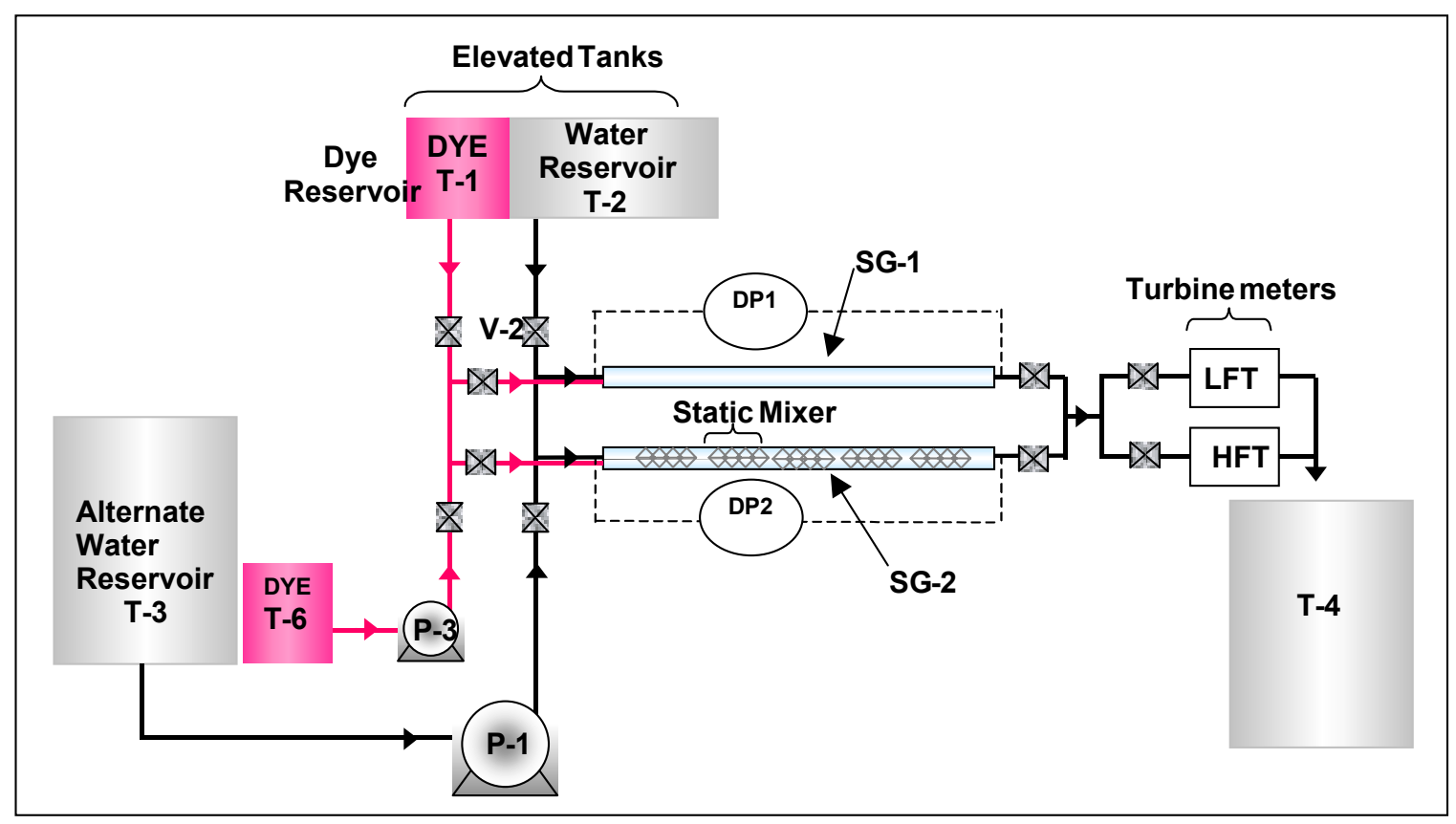

Figure 4. Schematic of laminar/turbulent flow demonstration module

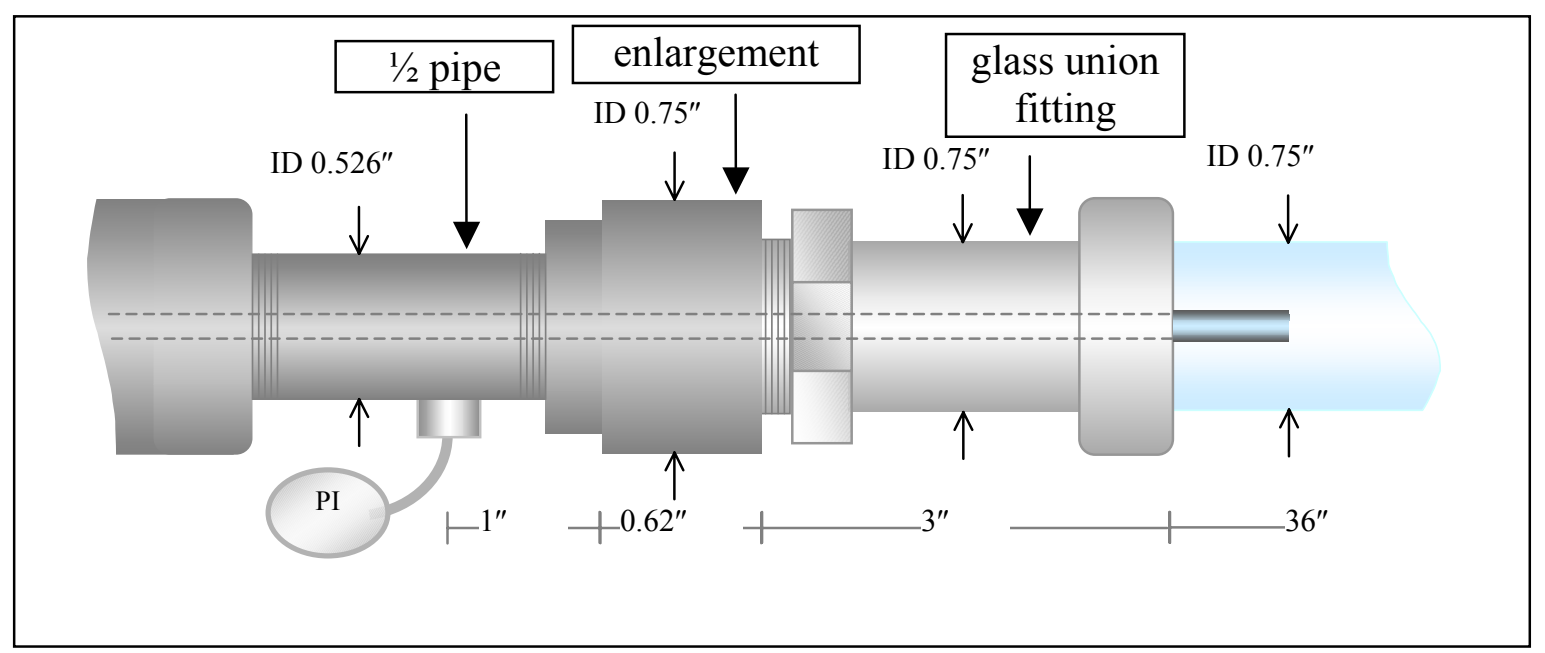

Figure 5. Detail drawing of the entrance fittings used for the glass tubes.

"Proceedings of the 2003 American Society for Engineering Education Annual Conference \& Exposition Copyright (C) 2003, American Society for Engineering Education" 


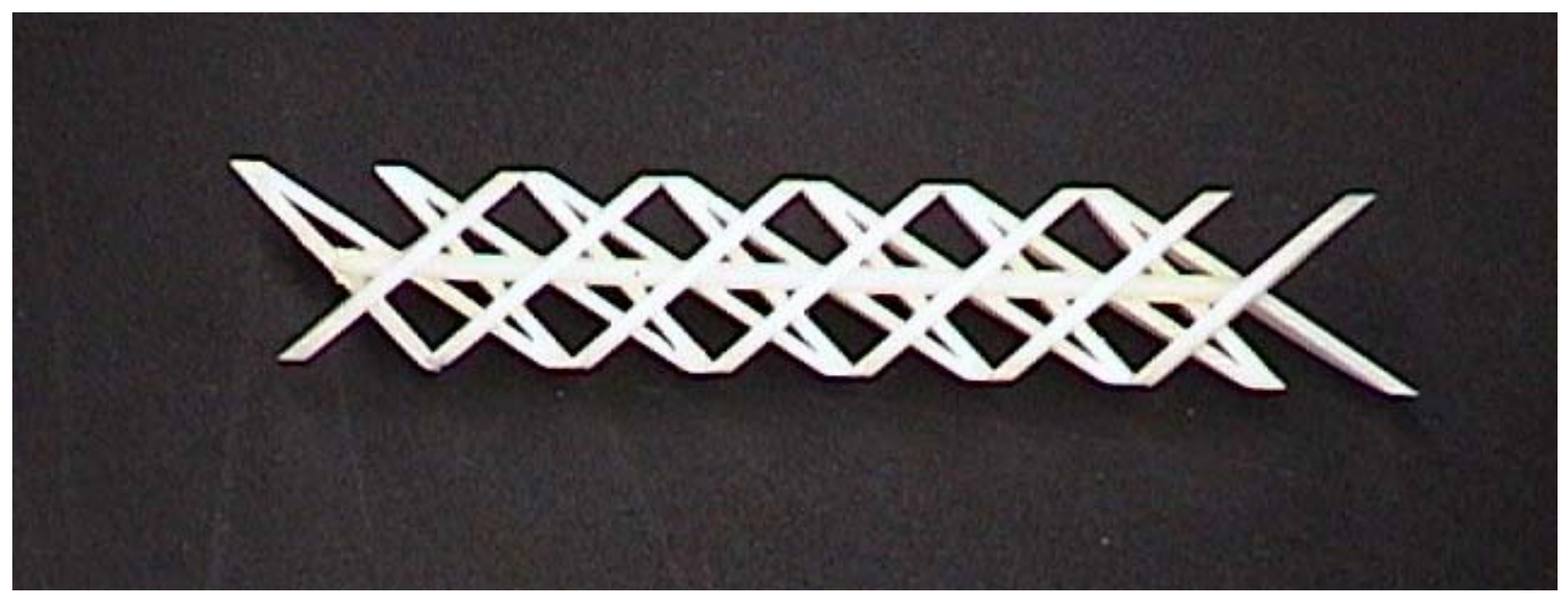

Figure 6. The Stata-tube ${ }^{\mathrm{TM}}$ PVC Series 50 static mixer

\section{Integration of the Laboratory into the Engineering Curriculum}

Presently, the module is used by two groups: Junior chemical engineering students taking experimental methods (units operations) as a separate course, and Junior mechanical engineering technology (MET) students taking a fluids mechanics laboratory. Broadly, the objectives include understanding and demonstrating the Reynolds number-friction factor relationship and observing the pressure drop characteristics in different flow regimes. Specifically, for the chemical engineers, the objectives include calibration of the turbine meters, calibration of the pressure transducers, acquisition of pressure drop as a function of flow rate for both sight glasses in all regimes, and the acquisition of a pump capacity curve data for one of the centrifugal pumps. A digital camera is provided so that students can photograph the flow streams they obtain at various flow rates. The equations needed to analyze data are covered in a previous chemical engineering course in fluid mechanics. We expect the students to will find these equations (friction factor, Reynolds number etc) in their textbooks before the laboratory begins. They perform the experiment in two 4-hour laboratory periods. A formal report is due the week following completion of the experiment. For the MET students, they acquired pressure drop data, and observe the flow regimes over the course of a one -2.5 hour laboratory period. Calibrations of the instrumentation are provided to these students.

\section{Results and Discussion}

Chemical engineering students use digital camcorders such as a Sony DCR-TRV 17 for a visual record of the various flow regimes using the dye trace regimes. This type of camera allows for stills and motion. A tripod is necessary to help hold the camera in place and at an even level during recording. Figure 7 shows students working on the experiment acquiring pressure drop data. An example of still shots acquired from a digital recording is shown in Figure 8 to highlight tracer lines in SG1 at various Reynolds numbers. An interesting observation from this figure is the sinking effect of the tracer stream for very low Reynolds number $(\operatorname{Re}=40)$. This may be due to the effect of density as the density of the water with the dye tablets measured at $0.9983 \mathrm{~g} / \mathrm{ml}$ versus $0.9981 \mathrm{~g} / \mathrm{ml}$ for tap water at $20^{\circ} \mathrm{C}$ using a Parr Densitometer. At $\mathrm{Re}=170$ we observe a very straight stream line. At $\mathrm{Re}=425$ we see slight waviness occurring but no eddying. At $\mathrm{Re}=970$ we see the onset of instability with much waviness. At $\mathrm{Re}=1390$, further instability

"Proceedings of the 2003 American Society for Engineering Education Annual Conference \& Exposition Copyright (C) 2003, American Society for Engineering Education" 
is observed. At $\mathrm{Re}=1750$ we see an onset of eddying (photograph not shown); however, the tracer stream still tends to stay in the middle of the tube as it flows downstream. By $\mathrm{Re}=3300$ the tracer is fully mixed into the stream within $3 \mathrm{~cm}$ of injection.

Figure 9 shows some streamlines photographed for SG2. We discovered after insertion of the 8 elements that full mixing occurs by the end of the first mixing element. At very low $\operatorname{Re}(\operatorname{Re}=20)$, the dye slowly disperses by diffusion before reaching the first static mixer. The velocity at this Re is approximately $0.1 \mathrm{~cm} / \mathrm{s}$. The distance from the ejection tube to the static mixer is $11.5 \mathrm{~cm}$. Thus, the residence time from time of ejection from the tube to the static mixer is about 115 seconds. At low $\operatorname{Re}(\operatorname{Re}=195)$ when the tracer stream is first injected, one can see the stream begins to wind and twist through the static mixer dividing up as it passes through. By the end of the first static mixer, the color is fully dispersed throughout the diameter of the tube. At $\operatorname{Re}=310$ the dye can be observed subdividing with the static mixer and mixing in quite rapidly as it passes through each division. At $\mathrm{Re}=930$ and 1115 , we see an onset of instability with the waviness appearing before reaching the static mixer. Full mixing within the static mixer is occurring within the first 4 or 5 divisions. At Re 3300 (photograph not shown), the dye is dispersed before it reaches the static mixer, indicating very rapid mixing and the lack of need for static mixer for the fluids under these conditions.

Figure 10 shows a laminar profile outlined by the tracer. A dark half-ellipse line has been added to highlight the parabolic nature of the flow stream. This situation was created by pulsing the dye for a moment and then turning off the pumps. As the flow rate relaxes, a square pulse disperses down the tube and appears as shown in Figure 10.

Figure 11 shows the pressure drop (dp) as function of flow rate for the two sight glasses. Several features about figure flow appear. Most obvious is that (dp) increases significantly by adding the eight static mixers $\left(\sim 100\right.$ fold). Secondly, each curve shows a region of $1^{\text {st }}$ order increase leading to a near $2^{\text {nd }}$ order increase in $(\mathrm{dp})$ as flow rate increases. Power fits of the data in the turbulent region for the two data sets give powers of 1.63 and 1.68 for SG1 and SG2 respectively. We also can see evidence of the inaccuracy in measuring (dp) at very low flow rates where the pressure drop appears to level out.

Figure 12 is the Fanning friction factor chart. The data parallel the lines for $\mathrm{f}$ as determined for smooth tubes. The pressure drop shift can be related to the equivalent length of the system being greater than the actual length of the tube. Applying Eqn 8 in the laminar regime and Eqn 9 in the turbulent regime, equivalent length can be estimated. The mean $\mathrm{L}_{\mathrm{eq}}$ of the 35 points shown in Figure 11 for SG1 is $8.6 \mathrm{ft}+/-1 \mathrm{ft}$. Table 1 shows a similar calculation using formulas found for the fittings and adjustments to the reference diameter of 0.75 inches. The calculated result, 104 inches $(8.67 \mathrm{ft})$, agrees with the experimental measurements. The sight glass with the static mixer calculates to an equivalent length of 530 feet, $\sim 62$ times longer than the empty sight glass. An equivalent length for eight elements of the static mixer (difference between 530 feet and 8.6 feet) is 521.4 feet. Thus, the equivalent length due to one static mixer is 65.2 feet of $3 / 4$ " glass tubing ignoring contraction and expansion changes due to the static mixer. From Figure 12 it can be seen that the onset of turbulent flow occurs at a Reynolds of 310 for SG2 (static mixer) and at 1000 for SG1 (empty glass tube). The fluid velocity increases $(\sim 20 \%)$ because the static mixer occupies a portion of the cross-sectional area of the tube. The fluid twisting and additional skin friction from the mixer element surfaces induces additional turbulence.

"Proceedings of the 2003 American Society for Engineering Education Annual Conference \& Exposition Copyright (C) 2003, American Society for Engineering Education" 
Table 1. Equivalent length determination of empty glass tube system

\begin{tabular}{|l|c|c|c|}
\hline \multicolumn{1}{|c|}{ Section } & $\begin{array}{c}\text { Actual Length } \\
\text { (inches) }\end{array}$ & $\begin{array}{c}\text { Actual ID } \\
\text { (inches) }\end{array}$ & $\begin{array}{c}\text { Equivalent Length } \\
\text { as 0.75" ID pipe } \\
\text { (inches) }\end{array}$ \\
\hline 1/2" Sch 80 pipe & 1.00 & 0.526 & 5.9 \\
\hline Enlargement 1 & 0.62 & 0.75 & 28.1 \\
\hline Glass Union Fitting & 3.00 & 0.75 & 3.0 \\
\hline Sight Glass Tube & 36.00 & 0.75 & 36.0 \\
\hline Glass Union Fitting & 3.00 & 0.75 & 3.0 \\
\hline Contraction 1 & 0.62 & 0.75 & 22.1 \\
\hline 1/2" Sch 80 pipe & 1.00 & 0.526 & 5.9 \\
\hline Total Length, inches & $\mathbf{4 5 . 2 4}$ & N/A & $\mathbf{1 0 4}$ \\
\hline
\end{tabular}

Students were major contributors to the evolution of this experiment. Students returning from co-op, with their practical experience, made several key suggestions including the addition of a dye to what was the original $\mathrm{pH}$ injection system.

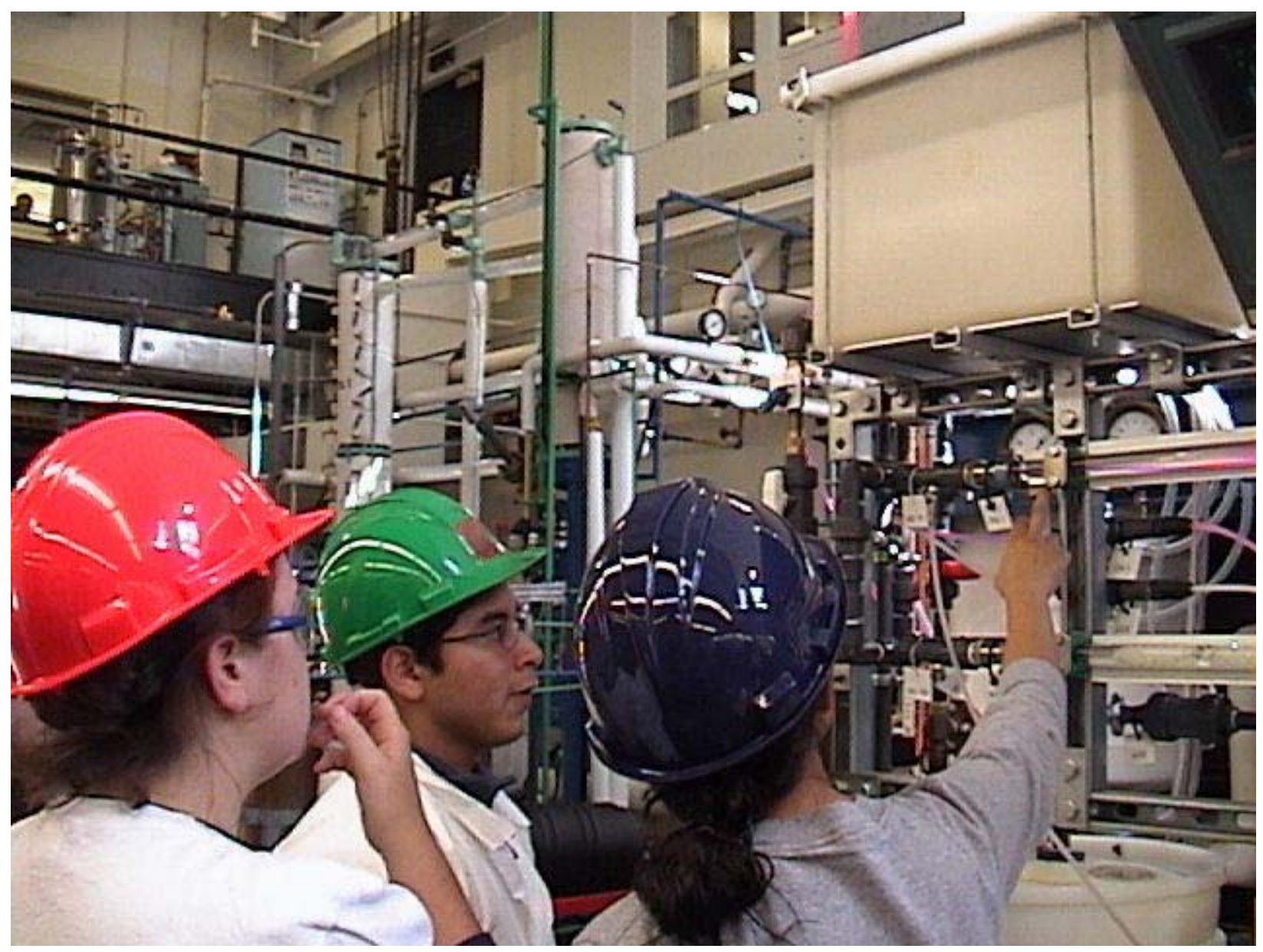

Figure 7. Students working on the experiment

"Proceedings of the 2003 American Society for Engineering Education Annual Conference \& Exposition Copyright (C) 2003, American Society for Engineering Education" 


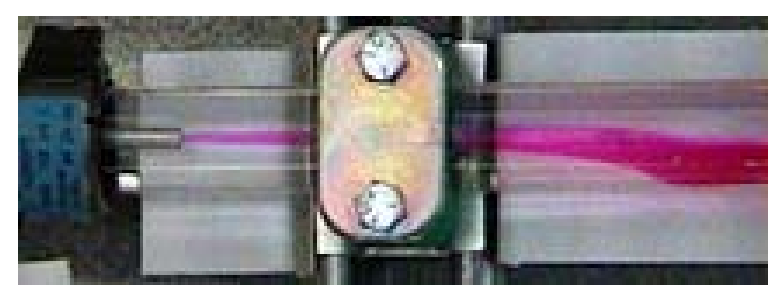

A: Empty Tube $\operatorname{Re}=40$

Dye spreads from density difference.

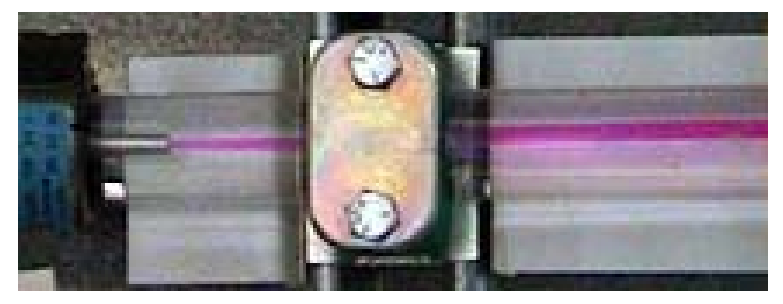

B. Empty Tube $R e=170$

Dye Streamlines

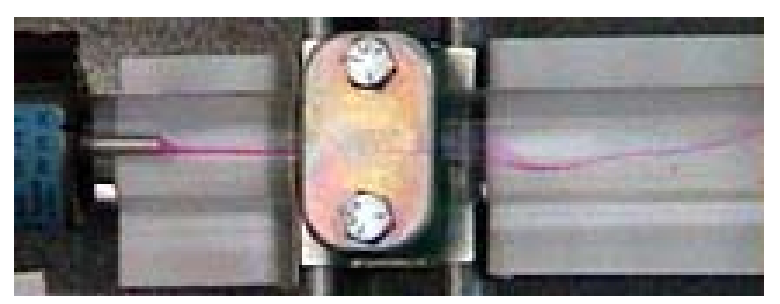

C. Empty Tube $\mathrm{Re}=425$

Dye streamlines, main flow in transition

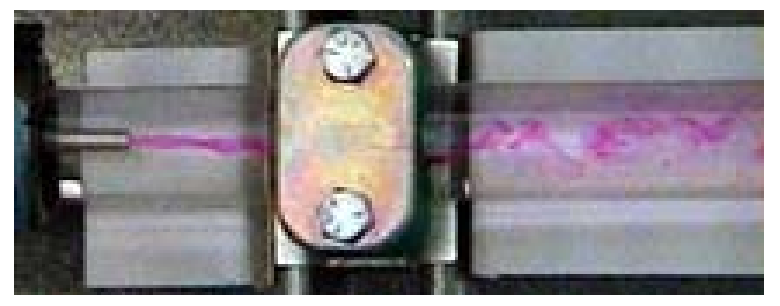

D. Empty Tube $R e=970$

Onset of instability

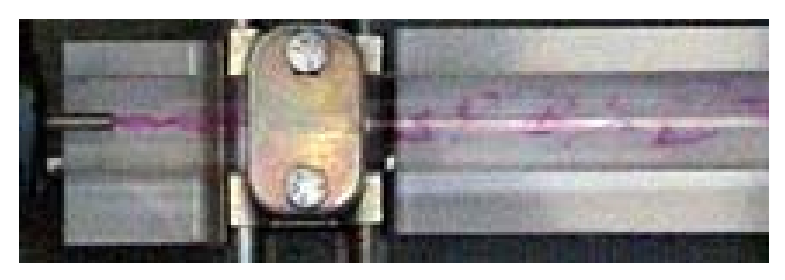

E. Empty Tube $R e=1390$

Further instability

Figure 8. Flow streams inside empty tube at various Reynolds numbers 


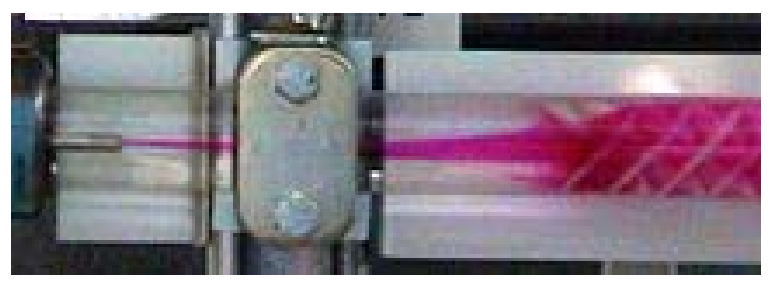

A. Mixer in Tube $\mathrm{Re}=20$

Dye spreads because of diffusion.

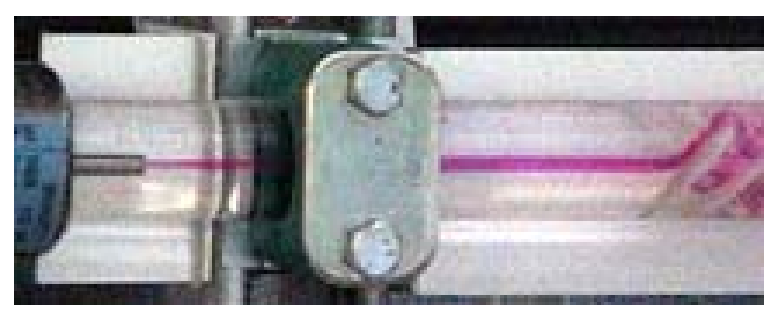

B. Mixer in Tube $\mathrm{Re}=195$

Dye streamlines in tube and mixer

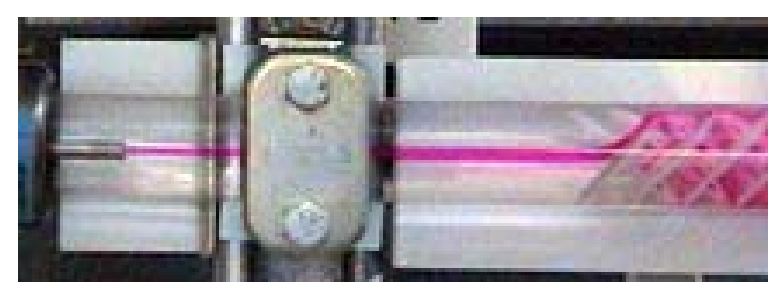

C. Mixer in Tube $R e=310$

Dye streamlines in tube, mixer flow in transition

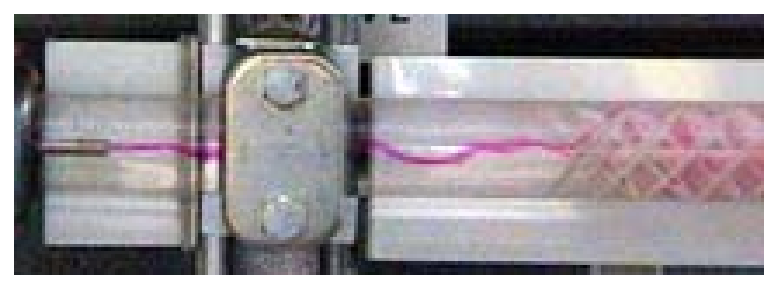

D. Mixer in Tube $R e=930$

Onset of instability

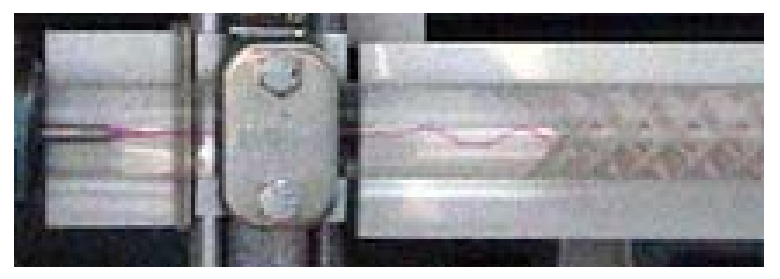

E. Mixer in Tube $\mathrm{Re}=1115$

Further instability

Figure 9. Flow Streams Inside Glass Tube with Static Mixer

"Proceedings of the 2003 American Society for Engineering Education Annual Conference \& Exposition Copyright (C) 2003, American Society for Engineering Education” 


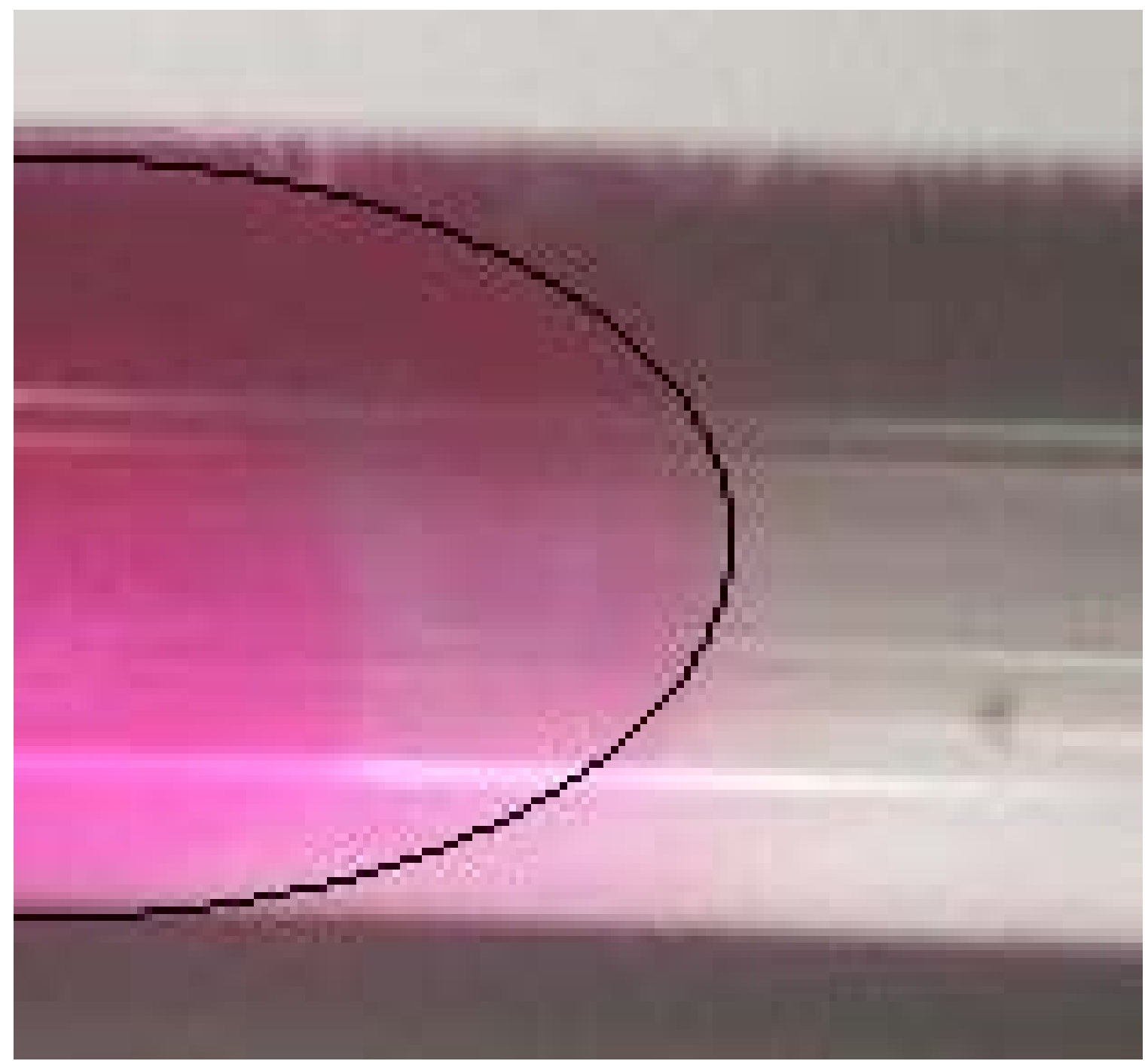

Figure 10. Pulse of dye in a very slow flowing stream

"Proceedings of the 2003 American Society for Engineering Education Annual Conference \& Exposition Copyright (C) 2003, American Society for Engineering Education" 


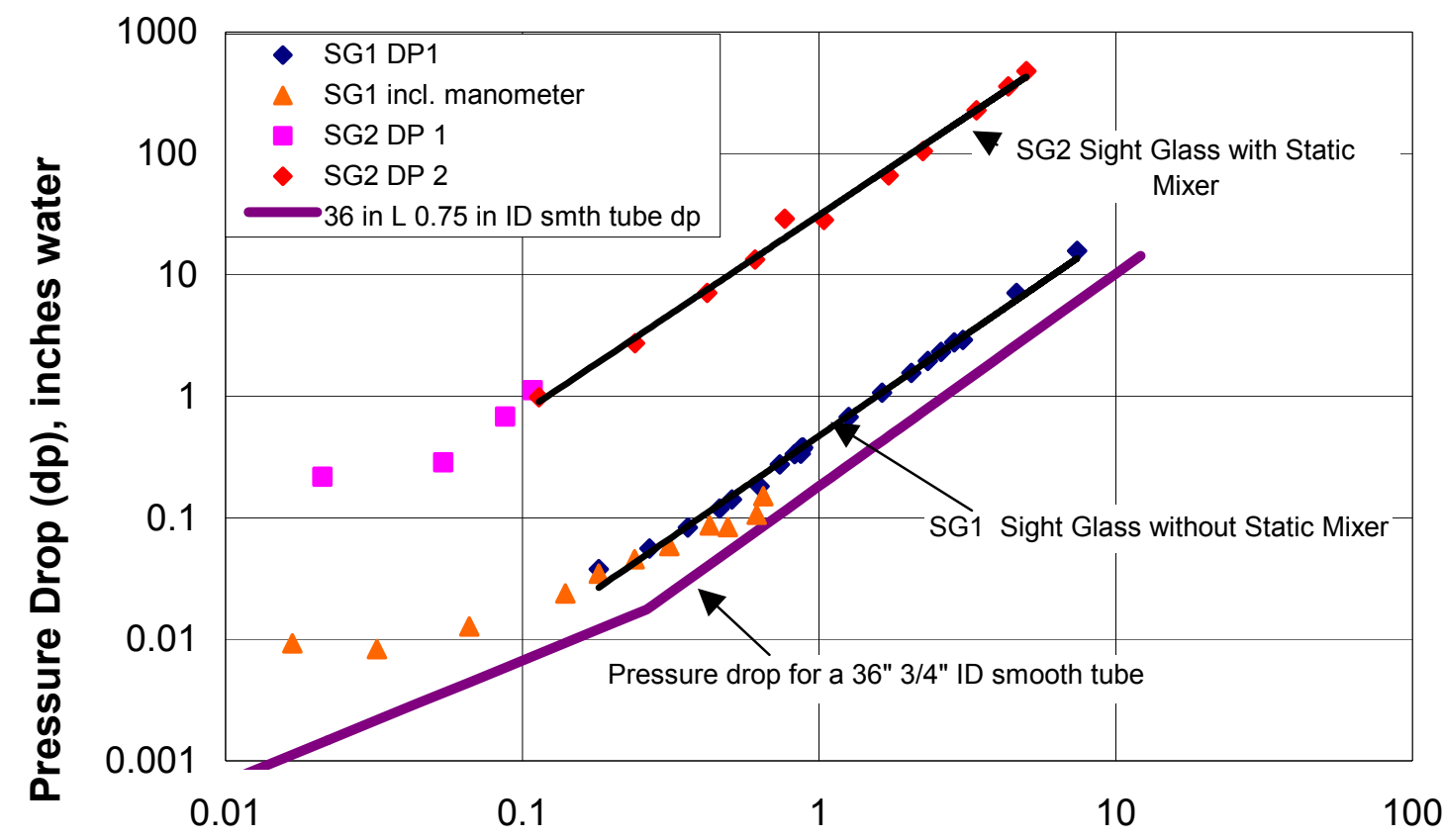

Flow Rate, gallons per minute

Figure 11. Pressure drop determined as a function flow rate for both tubes

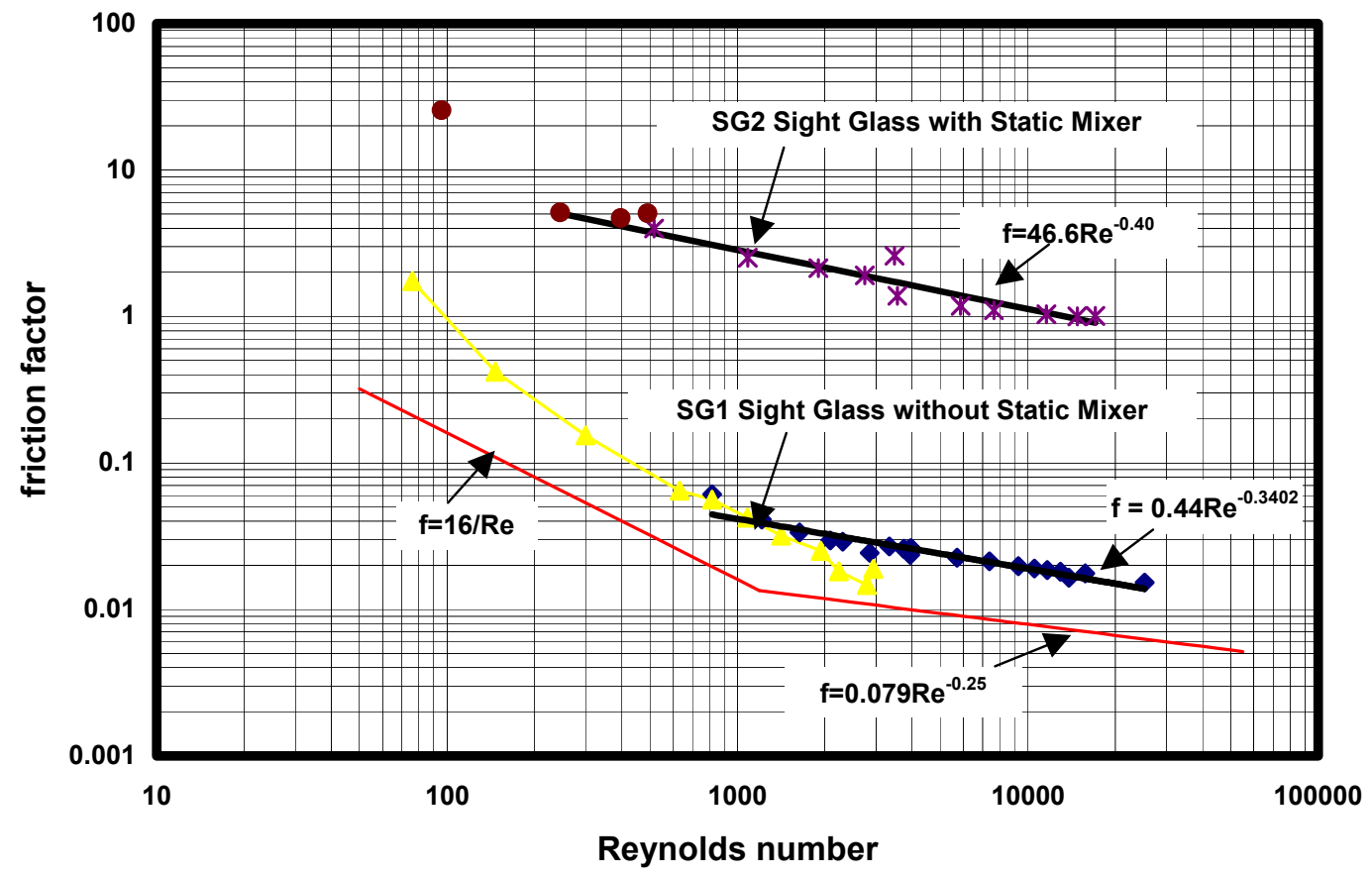

Figure 12. Friction factor as a function of Reynolds number for both tubes

"Proceedings of the 2003 American Society for Engineering Education Annual Conference \& Exposition Copyright (C) 2003, American Society for Engineering Education" 


\section{Conclusions}

1. A module allows demonstration of the various flow regimes for flow through pipes.

2. This module also demonstrates the effectiveness of in-line static mixers

3. The module demonstrates the increased pressure drop associated with in-line static mixers

4. Experimental pressure drop data acquired with this equipment agrees with established references in both the laminar and turbulent regimes.

5. The static mixer promotes turbulence at lower Reynolds numbers.

\section{Acknowledgement}

Equipment support for this experiment came through the donation of the $\mathrm{pH}$ control system by Solutia, Inc. (formerly the Monsanto Company) and by LMI Milton Roy of Acton, MA for the dye pulsation pumps. Laboratory Technologies Corporation of Andover, MA is acknowledged for the software used for data acquisition (LABTECH CONTROL PRO). Practical Applications, Inc. of Boston donated dye tablets. Paul DellaRocca is acknowledged as the first graduate student to undertake the initial design and set-up of the $\mathrm{pH}$ control experiment. Finally, Northestern University Department of Chemical Engineering is acknowledged for purchase of ancillary pieces as the project proceeded. 
Table 2. Specifications for Major Components Used on the Module

\begin{tabular}{|c|c|c|c|}
\hline Description & Manufacturer & Model Number & $\begin{array}{l}\text { Key Dimension } \\
\text { or Specifications }\end{array}$ \\
\hline Sight Glasses & Schott Process & US 026 & $\begin{array}{l}36 \text { inches long } \\
0.75 \text { inches ID }\end{array}$ \\
\hline Static Mixers & $\begin{array}{l}\text { Stata-tube }{ }^{T M} \text { PVC } \\
\text { mixer }\end{array}$ & Series 050-062 & $\begin{array}{l}8 \text { elements with } 14 \\
\text { CL stages in each }\end{array}$ \\
\hline $\begin{array}{l}\text { Incline Manometer Used } \\
\text { for Delta Pressure } \\
\text { Measurement Laminar } \\
\text { Flow }\end{array}$ & Merriam & & $\begin{array}{l}0 \text { to } 1 \text { inch water } \\
0.01 \text { inch } \\
\text { graduations }\end{array}$ \\
\hline $\begin{array}{l}\text { Low Range Differential } \\
\text { Pressure Transducer }\end{array}$ & $\begin{array}{l}\text { Omega } \\
\text { Engineering }\end{array}$ & PX 750 & $\begin{array}{l}0.5 \text { to } 30 \text { inches } \\
\text { water }\end{array}$ \\
\hline $\begin{array}{l}\text { High Range Differential } \\
\text { Pressure Transducer }\end{array}$ & $\begin{array}{l}\text { Omega } \\
\text { Engineering }\end{array}$ & PX750-750DI & $\begin{array}{l}30 \text { to } 850 \text { inches } \\
\text { water }\end{array}$ \\
\hline Dye Tablets & Lab Safety, Inc. & $\begin{array}{l}\text { Bright Dye }(\mathrm{P} / \mathrm{Nr} \\
23680)\end{array}$ & 1 per gallon \\
\hline $\begin{array}{l}\text { Supply Pump for } \\
\text { Turbulent Flow }\end{array}$ & March & AC-5C-MD & $\begin{array}{l}1 / 8 \mathrm{hp} 227 \text { Watts } \\
2.2 \text { amps }\end{array}$ \\
\hline $\begin{array}{l}\text { Supply Tank for Laminar } \\
\text { Flow }\end{array}$ & Nalgene & $\begin{array}{l}14100 \text { Heavy- } \\
\text { Duty }\end{array}$ & 13 "h x12"w x 18" \\
\hline $\begin{array}{l}\text { Supply Pump for Dye } \\
\text { Injection (Turbulent } \\
\text { Flow Conditions) }\end{array}$ & LMI, Milton Roy & A941-1585 & $\begin{array}{l}\text { Max GPH } 0.58 \\
50 / 60 \mathrm{~Hz} \\
\text { Max PSI } 250.0\end{array}$ \\
\hline Low Flow Turbine Meter & Hoffer & $\begin{array}{l}\text { MF1/2X100B- } \\
0.1-1-B-1 M-M S\end{array}$ & 0.1 to $1 \mathrm{gpm}$ \\
\hline $\begin{array}{l}\text { High Flow Turbine } \\
\text { Meter }\end{array}$ & Hoffer & $\begin{array}{l}\mathrm{HO} 1 / 2 \mathrm{X} 1 / 2- \\
1.25-9.5-\mathrm{C}-\mathrm{M}- \\
\text { NPT-IND }\end{array}$ & 1.25 to $9.5 \mathrm{gpm}$ \\
\hline $\begin{array}{l}\text { A/D Data Acquisition } \\
\text { Board }\end{array}$ & Keithley & EXP-16A & $\begin{array}{l}16 \text { differential } \\
\text { inputs } / 128 \text { analog } \\
\text { input channels }\end{array}$ \\
\hline Microcomputer & $\begin{array}{l}\text { Dell OptiPlex } \\
\text { GX1 }\end{array}$ & & \\
\hline $\begin{array}{l}\text { Software for Data } \\
\text { Acquisition }\end{array}$ & Labtech & $\begin{array}{l}\text { Labtech Control } \\
\text { Pro }\end{array}$ & \\
\hline
\end{tabular}

"Proceedings of the 2003 American Society for Engineering Education Annual Conference \& Exposition Copyright (C) 2003, American Society for Engineering Education" 


\section{References}

${ }^{1}$ Reynolds, O., Phil. Trans. Roy. Soc., 174, 935 (1883)

${ }^{2}$ Poiseuille, J. L. M., Comptes Rendus, 11, 961-967,1041-1048 (1840)

${ }^{3}$ Darcy, B.J. "Les fountaines publiques de la ville de Dijon" Victor Dalmont. Paris (1856).

${ }^{4}$ Jackson, J. D., "Osborne Reynolds Scientist, Engineer and Pioneer," http://www.eng.man.ac.uk/historic/reynolds/oreyna.htm, Access Date: 12/23/02

${ }^{5}$ Collier, J., "Portrait of Osborne Reynolds," http://www.eng.man.ac.uk/historic/reynolds/orey1904.jpg, Access Date: 12/23/02

${ }^{6}$ Batchelor, G. K.,"An Introduction to Fluid Dynamics," Cambridge University Press, (1979)

${ }^{7}$ Flometrics, I., "Reynolds Number Experiment," http://www.flometrics.com/reynolds_experiment.html, Access Date: 12/23/02

${ }^{8}$ Hesketh, R. P. and Slater, S., "Process Engineering Measurements - Week 3," http://engineering.eng.rowan.edu/ hesketh/www_old/processweek3/ProcessMeasurementswee k3.html, Access Date: 12/23/02

${ }^{9}$ Hesketh, R. P., Slater, C. S. and Farrell, S., ASEE Summer School,"The Role of Experiments in Inductive Learning Fluid Mechanics Experiments," CD ROM available from CACHE, see Iworkshops\Novel Laboratory Experiments $\backslash$ index.htm, (2002)

${ }^{10}$ Rossi, L., "The Wall Jet Page," http://www.math.udel.edu/ rossi/Research/wj/wj.html, Access Date: 12/23/02 (see ASEE Summer School CD ROM)

${ }^{11}$ Homsy, G.M., et al., Multi-Media Fluid Mechanics. 2000, Cambridge University Press, Cambridge, U.K.

${ }^{12}$ Klinzing, G., CEE, 32, 114-117, 155 (1998) (see ASEE Summer School CD ROM)

${ }^{13}$ Alves, M. A., Pinto, A. M. F. R. and Guedes de Carvalho, J., R. F., CEE, 33, 226-230 (1999)

${ }^{14}$ Lindeburg, M. R.,"Engineer-in-Training Reference Manual, 8th Ed", Professional Publications, Inc., Belmont, CA, pages 17-4 to 17-7 (1992)

${ }^{15}$ Henry, J., ASEE Summer School,"Laboratory and Web based Automation," CD ROM available from CACHE, see $\backslash$ workshops $\backslash$ Novel Laboratory Experiments lindex.htm, (2002)

"Proceedings of the 2003 American Society for Engineering Education Annual Conference \& Exposition Copyright (C) 2003, American Society for Engineering Education" 


\section{Biographies}

\section{Ronald J. Willey}

Professor Willey joined the Department of Chemical Engineering of Northeastern University in the Fall of 1983. His teaching is devoted to experimental methods and process safety. He is a registered professional engineer in the Commonwealth of Massachusetts and was recently elected Fellow of the AIChE.

\section{Guido W. Lopez}

Dr. Guido Lopez is a faculty member of the School of Engineering Technology at Northeastern University, Boston.. He previously served as Department Head of the Engineering Math and Science Division at Daniel Webster College, Nashua, NH. He has performed applied research at the NASA John Glenn Research Center on power generation for the international space station.

\section{Deniz Turan}

Ms Turan is a graduate of the Middle East Technical University (BS in Chemical Engineering), Ankara, Turkey in 2001. She joined Northeastern University as a research scholar in 2001 and became a teaching assistant in the unit operations laboratory in 2002. She also has co-op experience at Artisan Ind., Waltham, MA as a Project Engineer.

\section{Ralph A. Buonopane}

Dr. Buonopane is an emeritus professor and past chair of the Chemical Engineering Department at Northeastern University. He is a Fellow of ASEE and AIChE and has served on numerous ad hoc and standing committees of these organizations. He has served as an ABET evaluator for Chemical Engineering programs for many years.

\section{Alfred Bina}

Al Bina joined the chemical engineering department in 1987 as a laboratory technician. He is the chief laboratory technician for the Dept. of Chem. Eng.at NU. During his career at NU he has been involved with the upgrade of flow through pipe experiments, design of heat exchanger test units, and the installation of a 6" diameter, 7 stage, pilot scale glass distillation column.

"Proceedings of the 2003 American Society for Engineering Education Annual Conference \& Exposition Copyright (C) 2003, American Society for Engineering Education” 